проектів, анкетування, індивідуальних та тематичних бесід, конкурсів, ділових та рольових ігор, «телефону довіри» тощо.

Підсумовуючи вищесказане, можна зробити висновок, що тільки завдяки відповідальній просвітницькій роботі педагогів ДНЗ можна досягти ефективності у формуванні культури батьківства молодих сімей, налагодити партнерські стосунки, які б гарантували всім учасникам освітнього процесу рівність у розв'язанні спільних задач, право на активну та конструктивну позицію, актуалізувати педагогічний потенціал молодої сім'ї, плекати свідоме ставлення до материнських та батьківських функцій, збагачувати виховні уміння молодої сім’ї та підтримувати упевненість батьків у своїх педагогічних можливостях.

Перспективи подальших розвідок убачаються в проектуванні системи роботи дошкільного навчального закладу з формування культури батьківства молодих сімей.

\title{
Література
}

1. Базова програма розвитку дитини дошкільного віку «Я у Світі» / М-во освіти і науки України; Акад. пед. наук України; наук. ред. та упоряд. О. Л. Кононко. - К. : Світич, 2008. - 430 с. 2. Воспитатели и родители / [сост.: Л. В. Загик, В. М. Иванова]. - М. : Просвещение, 1985. - 96 с. 3. Деснова І. С. Шляхи взаємодії педагогів із батьками дітей раннього віку / I. С. Деснова // Дошкільна освіта. - 2007. - №4 (18). - С. 39-41. 4. Доронова Т. Взаимодействия дошкольного учреждения с родителями / Т. Доронова // Дошкольное воспитание. - 2004. - №1. - С. 60-68. 5. Ладивір С. Секрети батьківської педагогіки / С. Ладивір // Дошкільне виховання. - 2008. - № 6. С. 3-6. 6. Пагута T. І. Співробітництво вихователів дошкільних закладів із сім'єю по вихованню дошкільників в дусі миру: автореф. дис. канд. пед. наук: спец. 13.00.01 «Теорія та історія педагогіки» / Т. І. Пагута. - Київ, 1997. - 24 с. 7. Проект Концепції розвитку дошкільної освіти на 2010-2016 pp. [Електронний pесурс]. - Режим доступу: http: // civic.kmu.gov.ua/civic/control/uk/discussion/ovv/project;jssesionid= 442 F8B56393353760C6E281346AD. 8. Товкач I. Є. Хочу бути мамою, хочу бути татом: [ навч.-метод. посіб.] / I. С. Товкач - К. : ВД «Слово», 2012. -368 с.

УДК 373:37.014.15(477) «20»

H. С. Гарань,

acniрант,

Донбаський державний педагогічний університет

\section{СТВОРЕННЯ НОРМАТИВНО-ПРАВОВОЇ БАЗИ ДОШКІЛЬНОЇ ОСВІТИ УКРАЇНИ (2000-2012 рр.)}

Гарань Н. С. Створення нормативно-правової бази дошкільної освіти України (2000-2012рр.)

Стаття продовжує цикл публікацій автора, присвячених дослідженню розвитку системи дошкільної освіти України. Мету пропонованої статті автор убачає в тому, щоб презентувати питання нормативно-правового забезпечення дошкільної освіти України. Автор намагається у хронологічній послідовності розглянути етапи створення правової бази дошкільної освіти України упродовж 2000-2012 pp.

Ключові слова: система дошкільної освіти, дитячий садок, нормативно-правова база, навчальновиховний процес, дошкільна освіта.

Гарань Н. С. Создание нормативно-правовой базы дошкольного образования Украины (2002012 pp.)

Статья продолжает цикл публикаций автора, посвященных исследованию развития системы дошкольного образования Украины. Цель предлагаемой статье автор усматривает в том, чтобы презентовать вопросы нормативно-правового обеспечения дошкольного образования Украины. Автор пытается в хронологической последовательности рассмотреть этапы создания правовой базы дошкольного образования Украины на протяжении 2000-2012 гг.

Ключевые слова: система дошкольного образования, детский сад, нормативно-правовая база, учебно-воспитательный процесс, дошкольное образование. 
Haran N. S. Creation of the normative-legal framework preschool of education of Ukraine (2000-2012 years).

Article continues the series of publications of the author on the study of the development of pre-school education system of Ukraine. The purpose of the proposed article, the author sees in fact, to present the issues of normative-legal support of pre-school education of Ukraine. The author tries to in chronological sequence to consider the stages of creation of the legal base of pre-school education of Ukraine for 20002012 years.

Key words: the system of pre-school education, children's garden, the normative-legal base, training of the educational process, pre-school education.

Наголосимо, що успіхів у будь-якій галузі можна досягти лише за наявності відповідної нормативно-правової бази, що створює умови задля розвитку особистості.

В останні роки державою та відповідними органами влади України вжито заходів щодо створення нормативно-правової бази дошкільних установ.

Питанню аналізу нормативно-правової бази функціонування дошкільної освіти приділено увагу в наукових працях: А. Богуш [1], О. Кононко [2], Н. Лисенко [3], Н. Омеляненко [4], Т. Пантюк [6; 7], С. Пехарєва [9], О. Янко [18].

Mema cmammi полягає в тому, щоб проаналізувати нормативно-правову базу вітчизняної дошкільної освіти протягом 2000-2012 pp.

Провідні принципи сучасної української системи дошкільної освіти задекларовано в низці загальнодержавних нормативних документів, а саме: в Державній національній програмі «Освіта» (Україна XXI століття), «Національній доктрині розвитку освіти України у XXI столітті», Законі «Про дошкільну освіту», «Про охорону дитинства», Базовому компоненті дошкільної освіти (нова редакція), Державній цільовій програмі розвитку дошкільної освіти на період до 2017 р., у яких позиціонується необхідність наукового забезпечення модернізаційних процесів у вітчизняній системі освіти щодо відповідності її сучасним світовим тенденціям.

Вперше в історії дошкільного виховання було прийнято Закон України «Про дошкільну освіту» (2001р.), який визнав дошкільну освіту обов'язковою первинною складовою частиною системи неперервної освіти в Україні [5].

У березні 2003 р. вийшла в світ постанова № 305 від 13.03.2003 р. «Про затвердження Положення про дошкільний навчальний заклад». Положення поширювалося на всі дошкільні навчальні заклади, визначало типи дошкільних навчальних закладів, окреслювало організаційно-правові засади діяльності дошкільного закладу, питання організації навчально-виховного процесу, харчування та медичного обслуговування, управління та фінансування [11, с. 15-26]. Дане Положення з часом зазнало певних змін, до нього були внесено доповнення й корективи, його нова редакція у 2011 р. [14, с. 41-55].

Відповідно до Закону України «Про дошкільну освіту» та Положення про дошкільний навчальний заклад діти могли відвідувати дошкільні заклади за різними режимами перебування, в тому числі i короткотривало (до чотирьох годин). Короткотривале перебування у дитячому садку передбачалося для дітей віком від 2 років 6 місяців до 6 (7) років, які з певних причин не мали можливості відвідувати заклад дошкільної освіти за повним режимом перебування (10,5-12 годин) і забезпечувало їхнє право на здобуття дошкільної освіти [15, с. 86-88].

Організація навчально-виховної діяльності з дітьми дошкільного віку 3 повним або короткотривалим перебуванням здійснювалася відповідно до вимог методичного листа Міністерства освіти і науки України «Організація та зміст навчально-виховного процесу» № 1/9-306 від 06.06.2005 р.

Задля встановлення єдиних вимог щодо комплектування дошкільних навчальних закладів або груп компенсуючого типу для дітей, які потребували корекції фізичного або розумового розвитку, Міністерством освіти і науки України разом із Міністерством охорони здоров'я України було затверджено та видано Наказ «Порядок комплектування дошкільних навчальних закладів (груп) компенсуючого типу» № 240/165 від 27.03.2006 р. 
Для задоволення існуючих освітніх потреб громадян, а також за необхідності можуть створюватися дошкільні навчальні заклади із сезонним перебуванням дітей, які входять до складу навчально-виховного комплексу або до складу об'єднання з іншими навчальними закладами; що функціонують неповний календарний рік, але не менше як три місяці на рік. До таких закладів приймають дітей від двох місяців до 6 (7) років. Нормативноправові основи діяльності таких сезонних дошкільних установ закріплені документом «Про організацію роботи дошкільного навчального закладу з сезонним перебуванням дітей» від 26.11.2009 p [16, с. 28-32].

Діяльність будь-якого закладу системи дошкільної освіти регламентується планом, у якому визначається мета, завдання, зміст, форми і методи роботи. Для подальшого вдосконалення роботи дошкільних установ на початку 2009-2010 н.р. було видано нормативний документ «Планування роботи в дошкільних навчальних закладах», який чітко визначав принципи планування роботи [10, с. 16-20].

Законом України «Про внесення змін до законодавчих актів 3 питань загальної середньої та дошкільної освіти щодо організації навчально-виховного процесу» у 2010 р. було введено обов'язкове здобуття дошкільної освіти дітьми п'яти років. Цей документ спрямований на реалізацію права кожної дитини на доступність дошкільної освіти, повноцінний фізичний, інтелектуальний, моральний, естетичний, соціальний розвиток та забезпечення рівних стартових можливостей майбутнім першокласникам перед вступом до школи.

Упродовж 2010-2011 н.р. було вжито дієвих заходів щодо розвитку та поліпшення стану й якості дошкільної освіти: прийнято Державну соціальну цільову програму розвитку дошкільної освіти на період до 2017 р. Уперше в історії освіти України 5 листопада 2010 р. проведено I всеукраїнський з'їзд педагогічних працівників дошкільної освіти [8, с. 12-28]; делегати з'їзду від Донецького регіону висвітлили питання стану дошкільної освіти, визначили перспективи її розвитку. За підсумками з’їзду в наступні роки заплановано створити демократичну систему управління освітою, вжити заходів щодо індивідуалізації освітнього процесу за рахунок збереження та розвитку багатофункціональної системи дошкільних закладів.

Унесено зміни до Положення про дошкільний заклад, які затверджено Постановою Кабінету Міністрів України від 16.11.2011 р. № 1204. Окресленими змінами урегульовано питання щодо оформлення в поліклініці медичної довідки про стан здоров'я дитини, що надається під час ï̈ прийому до дошкільного навчального закладу. Також визначено, що переведення дітей 3 однієї вікової групи до іншої, формування новостворених груп здійснюється наприкінці оздоровчого періоду [14]

Напередодні 2011-2012 навчального року Міністерство освіти і науки видало низку нормативних документів, які регламентували питання дошкільної освіти. Серед основних - інформаційні листи № 1/9-552 від 21.07.2011 р. «Щодо терміну перебування дітей, які досягли шестирічного віку, у дошкільних навчальних закладах», № 1/9-645 від 25.08.2011 р. «Про комплектування штатів дошкільних навчальних закладів, що вводяться в експлуатацію», інструктивно-методичні рекомендації «Про забезпечення взаємодії в освітній роботі з дітьми старшого і молодшого шкільного віку».

Законом України «Про дошкільну освіту» встановлено, що зміст дошкільної освіти визначає освітній стандарт - Базовий компонент дошкільної освіти. У ньому зведено норми і положення, що визначають державні вимоги до рівня освіченості, розвиненості і вихованості дитини шести (семи) років; сумарний кінцевий показник набутих компетенцій випускником дошкільного закладу перед вступом його до школи. Вимоги підлягають перегляду й осучасненню не рідше ніж один раз на десять років. Зазначимо, що попередній варіант Базового компоненту було прийнято ще у 1998 році.

Оновлена редакція Базового компоненту дошкільної освіти України схвалена рішенням колегії Міністерства освіти і науки, молоді та спорту України № 5/2-2 04.05.2012 р. У 
новому стандарті дошкільної освіти враховано всі найкращі напрацювання сьогодення, а також передовий досвід попередніх років [17].

Ураховуючи необхідність поширення мережі дошкільних закладів усіх типів і форм власності, для забезпечення права дітей на дошкільну освіту та створення рівних стартових можливостей, Міністерством освіти і науки, молоді та спорту розроблено та введено в дію Положення про дошкільний навчальний заклад сімейного типу [5].

Створення та відкриття закладів такого типу сприятиме забезпеченню більшої єдності виховних впливів родини та дошкільного навчального закладу, вчасного та повноцінного фізичного, інтелектуального, морального, естетичного і соціального розвитку дітей дошкільного віку відповідно до задатків, нахилів, здібностей та індивідуальних особливостей. Виховання та навчання дітей в умовах дошкільного навчального закладу сімейного типу має здійснюватися відповідно до вимог Базового компонента дошкільної освіти з максимальним використанням досвіду народної педагогіки.

Незважаючи на зміни курсу керівництва держави щодо ролі та місця дошкільної освіти, ухвалення великої кількості нормативно-регламентуючих документів, проведену значну практичну роботу, не можна не визнавати того факту, що система дошкільної освіти як Донецького регіону, так і України в цілому помітно відстала від дошкільної ланки передових країн світу, втратила помітні здобутки і переваги відпрацьованої в минулому системи освіти дітей дошкільного віку.

\section{Література}

1. Богуш А. Вектор наступності державних стандартів дошкільної і початкової освіти / Алла Богуш // Дошкільне виховання. - 2012. - № 7 - С. 20-21. 2. Кононко О. Базовий компонент дошкільної совіти: концептуальні засади, зміст і перспективи впровадження у практику / Кононко О. // Педагогічна газета. - 2000. - № 7. - С. 4-5. 3. Лисенко Н. Нові пріоритети педагогіки дошкілля в Україні / Н. Лисенко // Вісник Прикарпатського університету. Педагогіка. - Івано-Франківськ, 2000. - Вип. 4. С. 82-90. 4. Омеляненко Н. Дошкільна освіта: від концепції до програми / Ніна Омеляненко // Коментар до Інформаційного збірника Міністерства освіти і науки України. - 2010. - № 8 - С. 13-23. 5. Освіта України. Нормативно-правові документи. - К. : Міленіум, 2001. - 472 с. 6. Панасюк Т Два важливі документи в дошкіллі / Тамара Панасюк // Дошкільне виховання. - 2012. - № 6. - С. 2-3. 7. Панасюк Т. Розвиток дошкільної освіти: досягнення і перспективи / Тамара Панасюк // Дошкільне виховання. - 2012. - № 1. - С. 2-3. 8. Перший в історії незалежної України з’їзд працівників дошкільної освіти відбувся / Олег Єрєсько, Тамара Панасюк // Коментар до Інформаційного збірника Міністерства освіти і науки України. - 2010. - № 11. - С. 12-28. 9. Пехарєва С. В. Управління інноваційним розвитком дошкільного навчального закладу : автореф. дис. на здобуття наук. ступеня канд. пед. наук : 13.00.06 / Світлана Вікторівна Пєхарєва. Луганськ, 2009. - 20 с. 10. Планування роботи в дошкільних навчальних закладах № 1/9-455 від 03.07.2009 p. // Інформаційний збірник Міністерства освіти і науки України. - 2009. - № 22-23-24. C. 16-20. 11. Положення про дошкільний навчальний заклад // Інформаційний збірник Міністерства освіти і науки України. - 2003. - № 8. - С. 15-26. 12. Положення про дошкільний навчальний заклад сімейного типу // Інформаційний збірник та коментарі Міністерства освіти і науки, молоді та спорту України. - 2012. - № 3. - С. 18-26. 13. Порядок комплектування дошкільних навчальних закладів (груп) компенсуючого типу. Наказ № 240/165 від 27.03.2006 р. // Інформаційний збірник Міністерства освіти і науки України. - 2006. - № 15. - С. 4-10. 14. Про внесення змін до Положення про дошкільний навчальний заклад. Постанова Кабінету Міністрів України № 1204 від 16.11.2011 р. Положення про дошкільний навчальний заклад // Інформаційний збірник Міністерства освіти і науки України. - 2011. - № 34-35. - С. 41-55. 15. Про організацію короткотривалого перебування дітей у дошкільних закладах № 1/9-431 від 17.08.2005 p. // Інформаційний збірник Міністерства освіти і науки України. - 2005. - № 25-26-27. - С. 86-88. 16. Про організацію роботи дошкільного навчального закладу з сезонним перебуванням дітей № 1/9-812 від 26.11.2009 р. // Інформаційний збірник Міністерства освіти і науки України. - 2009. - № 34. - С. 28-32. 17. Про схвалення нової редакції Базового компонента дошкільної освіти. Рішення колегії Міністерства освіти і науки, молоді та спорту України № 5/2-2 04.05.2012 р.; Базовий компонент дошкільної освіти України // Інформаційний збірник та коментарі Міністерства освіти і науки, молоді та спорту України. - 2012. № 13-14-15. - С. 38-64. 18. Янко О.В. Організаційно-педагогічні умови управління якістю роботи 
сучасного дошкільного навчального закладу : автореф. дис. на здобуття наук. ступеня канд. пед. наук : 13.00.06 / Олена Вікторівна Янко. - Луганськ, 2009. - 20 с.

УДК 811.111(07):378.147

О. В. Гладка,

кандидат пед. наук, доиент,

Криворізький педагогічний інститут

ДВНЗ «Криворізький наиіональний університет»

\section{АКТИВІЗАЦІЯ ПІЗНАВАЛЬНОЇ ДІЯЛЬНОСТІ МАЙБУТНІХ УЧИТЕЛІВ У ПРОЦЕСІ ВИВЧЕННЯ ІНОЗЕМНОЇ МОВИ}

Гладка О.В. Активізація пізнавальної діяльності майбутніх учителів у процесі вивчення іноземної мови.

У статті доведено необхідність активізації пізнавальної діяльності майбутніх учителів у процесі вивчення іноземної мови та запропоновано найбільш ефективні сучасні методи, які сприяють успішному розв'язанню цього завдання.

Ключові слова: пізнавальна діяльність, активізація, майбутній учитель, метод.

Гладкая Е. В. Активизация познавательной деятельности будущих учителей в процессе изучения иностранного языка.

В статье доказана необходимость активизации познавательной деятельности будущих учителей в процессе изучения иностранного языка и предложены наиболее эффективные современные методы, способствующие успешному решению данной задачи.

Ключевые слова: познавательная деятельность, активизация, будущий учитель, метод.

Hladka O. V. Activation of future teachers' cognitive activities in the process of learning foreign languages.

In the article the necessity of activation of future teachers' cognitive activities in the process of learning foreign languages is proved. The most effective modern methods favoring the successful solution of the given task are suggested.

Key words: cognitive activities, activation, future teacher, method.

Інтеграція України до Свропейської спільноти, приєднання вітчизняної системи вищої освіти до Болонської декларації, орієнтація на Загальноєвропейські Рекомендації з мовної освіти [2] та пріоритетні напрямки «Національної доктрини розвитку освіти в Україні у XXI столітті» [5] передбачають зацікавленість інформаційного суспільства в особистостях, які володіють іноземною мовою, здатні до творчої праці, професійного розвитку, самостійної й активної діяльності, прийняття рішень, адаптації до мінливих умов сьогодення.

Незважаючи на впровадження технології особистісно-зорієнтованого навчання та необхідність реформ, освітня практика в педагогічних ВНЗ все ще спрямована на передачу максимального обсягу знань, недооцінює розвиток особистості тих, хто навчається, не забезпечує професійну успішність майбутніх учителів.

Розв'язання цієї проблеми - у цілеспрямованій активізації пізнавальної діяльності студентів, що сприяє їх саморозвитку, самореалізації, досягненню високого рівня професіоналізму, озброює їх умінням засвоювати новий матеріал, вчитися впродовж життя, успішно передавати знання і досвід наступним поколінням.

Питанням формування та активізації пізнавальної діяльності студентів в останні роки опікувалися С. Абрамов, С. Вахрушева, Е. Дмитриева, І. Засядько, Т. Квач, Л. Конопляник, Г. Кулагіна, Ю. Насонова, О. Олексюк, Б. Палмер, I. Степанова, О. Шишкова, Г. Шумахер. Однак, у теорії і практиці вищої педагогічної освіти недостатньо вивченою залишається проблема активізації пізнавальної діяльності майбутніх учителів у процесі вивчення іноземної мови. 